\author{
A.Zh. Sarsenbekova ${ }^{1}$, A.I. Khalitova ${ }^{2}$, A.A. Shakhabayeva ${ }^{1}$ \\ ${ }^{1}$ Karaganda State Medical University, Kazakhstan; \\ ${ }^{2}$ Ye.A. Buketov Karaganda State University, Kazakhstan \\ (E-mail: chem_akmaral@mail.ru)
}

\title{
Processing of hydrogel isotermic data on the base of polymethyl vinyl ether of maleic acid cross linked with polypropylene glycol under thermogravimetric data
}

\author{
Comparative kinetic analysis by NPK method
}

\begin{abstract}
Analysis of different computational methods for kinetic parameters of hydrogel thermal degradation on the base of polymethyl vinyl ether of maleic acid cross linked with polypropylene glycol under thermogravimetric data is presented. Researches were made in a nitrogen and air atmosphere at different heating rates: $6,10,12$ and $16 \mathrm{~K} / \mathrm{min}$. It was demonstrated that it makes sense to apply approaches of Friedman, Ozawa-Flynn-Wall, related to group of isoconversion methods. Obtained data indicate decentish coincidence between values of activation energy obtained by different methods. To get complete kinetic analysis, it is necessary to process data applying the method of non-parametric kinetics. Non-parametric kinetics method (NPK) is a special approach for processing of kinetic data. Method is a new viewpoint to kinetic analysis, which is based upon rounding of results of single-stage process kinetics. Experimental values of response time are located in the matrix, which is expressed as multiplication of two vectors, containing the information on $f(T)$ and $g(\alpha)$.
\end{abstract}

Keywords: dynamic thermogravimetry, thermal analysis, thermal destruction, hydrogel.

\section{Introduction}

Using the method of differential thermal analysis, we can identify such important parameters of polymers as phase transitions, radiation damages in polymeric materials, the heat of absorption and polymerization of the cross-linking, oxygenation and decomposition processes, concentration of the registered components of impurities etc [1].

High accuracy and sensitivity of the differential scanning calorimeter allow us to determine phase transitions of oxygenation and decomposition processes and etc., when we use samples of high-molecular composition which masses are equal to a few milligrams [2]. Of course, that the determination of kinetic parameters of decomposition reactions of polymers in isothermal conditions gives more accurate and valid results, but this method is labor consuming and requires considerable time and the use of large number of samples.

Goal of this work is to study and compose the academic kinetic model of hydrogel thermal decomposition on the basis of polymethyl vinyl ether of maleic acid cross linked with polypropylene glycol by nonlinear regression of thermo gravimetric analysis (TGA) isothermal curves.

\section{Experimental}

Poly(methyl-vinyl-co-maleic acid) or polymethylvinyl maleic acid ether (PMVE-MA) was obtained by hydrolysis polymethylvinyl ether of maleic anhydride (PMVE-MAH):

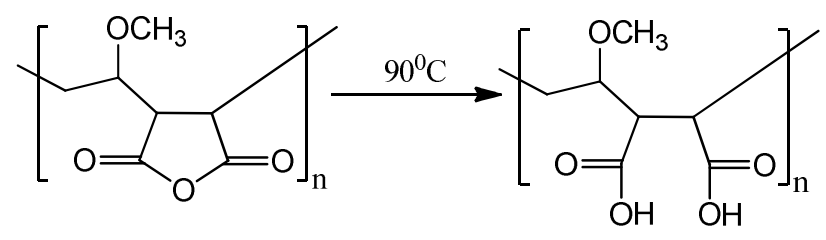

Process was held on assembly of round-bottomed flask with volume of $100 \mathrm{ml}$ and backflow condenser. Base mixture was prepared of $0.6500 \mathrm{~g}$ of PMVE-MAH and $20 \mathrm{ml}$ of distilled water. Hydrolysis was carried at the temperature of $90^{\circ} \mathrm{C}$ during 2 hours. Gradually water solution of polypropylene glycol (PPG) was added to generated polymethylvinyl maleic acid ether (PMVE-MA) up to obtaining of homogenic mixture. Excess water was drained with rotary evaporator. Reaction mixture was firmed for 24 hours at $80^{\circ} \mathrm{C}$. In the 
result of etherification reaction between polymethylvinyl maleic acid ether and polypropylene glycol gel PMVE-MA with PPG was formed:

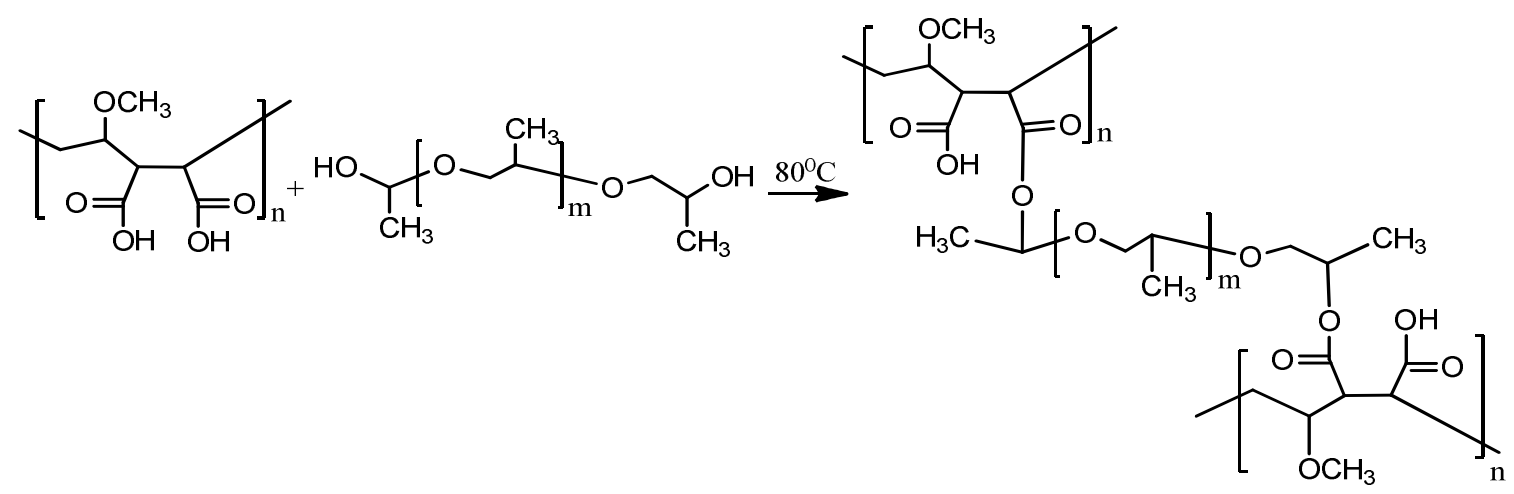

Study of hydrogel thermal properties was made with differential scanning calorimeter Labsys Evolution DTA/DSC of «Setaram» brand in dynamic regime with temperature range of $0-500{ }^{\circ} \mathrm{C}$ with heating rate of 6 , 10,12 и $16 \mathrm{~K} / \mathrm{min}$ in atmosphere of air and nitrogen in melter $\mathrm{Al}_{2} \mathrm{O}_{3}$.

All these calculations were performed with the use of the program MATLAB.

\section{Results and discussion}

Active substances were obtained by TGA analysis at heating rates $\beta=6,10,12$ and $16 \mathrm{~K} / \mathrm{min}$ in a nitrogen and air atmosphere. Kinetic analysis was held, applying isoconversion methods of Friedman (FR) [3] and Ozawa-Flynn-Wall (OFW) [4] for objective estimation of complex processes running parallel to thermal destruction, non-parametric kinetics method (NPK) was applied [5].

Thermal analytical values of hydrogel PMVE-MA with PPG decomposition are represented with thermal analytical curves TG (thermogravimetric), DTG (differential thermogravimetric) (Figs. 1, $a$ and $b$ ). According to figures 1 , $a$ and $b$, thermal decomposition of examined hydrogel PMVE-MA with PPG in a nitrogen atmosphere appears at the temperature of $265-335^{\circ} \mathrm{C}$ with peak DTG $=304{ }^{\circ} \mathrm{C}$, and in air atmosphere at $347-443{ }^{\circ} \mathrm{C}$ with peak DTG $=405^{\circ} \mathrm{C}$.
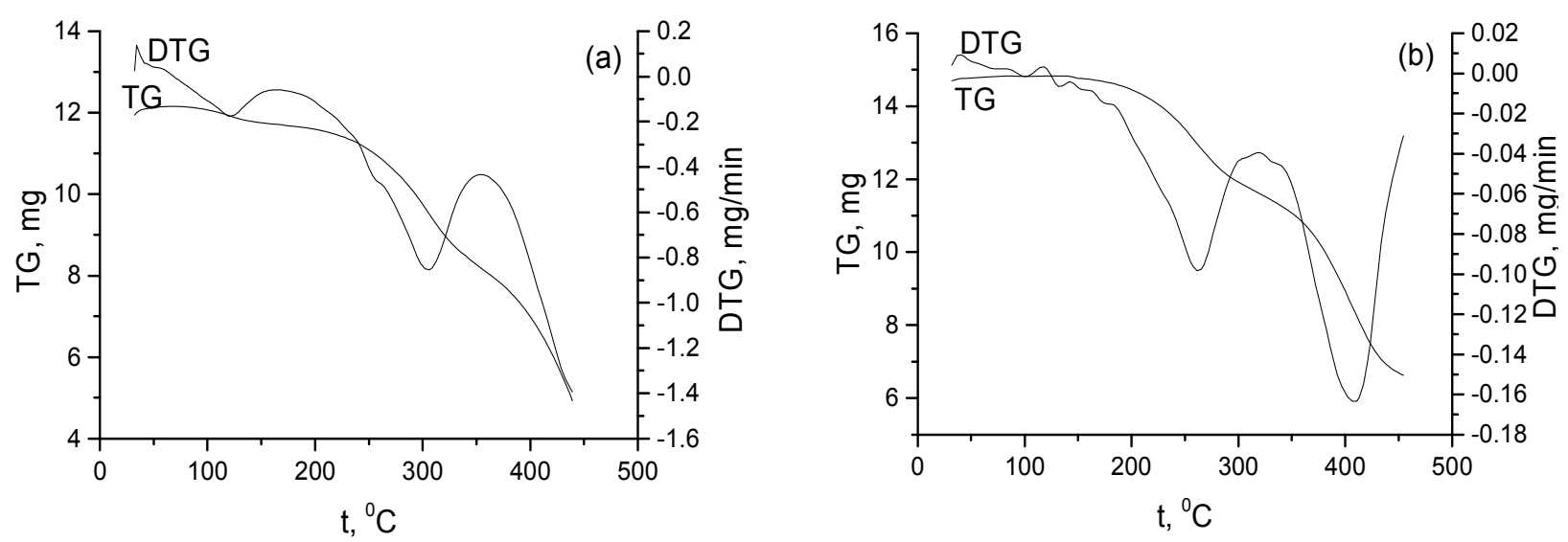

$a$ - in a nitrogen atmosphere; $b-$ in air

Figure 1 . The TG and DTG curves of the sample at a heating rate of $10 \mathrm{~K} / \mathrm{min}$

At temperature of $100-110^{\circ} \mathrm{C}$ weight loss in all samples amounts $5-10 \%$, which corresponds to the first decomposition process. Analysis of DTG curves (Figure 1, $a, b$ ) showed that desorbtion of associated water takes place up to temperature of $150{ }^{\circ} \mathrm{C}$. This fact may be explained by obstructivity of hydrogen bonds abruption between water molecules and polar function groups of gel PMVE-MA with PPG.

Second decomposition process includes the destruction of gel and reason of selected kinetic analysis. Isoconversion method is one of the methods for definition of activation energy; this method does not require knowledge on analytical form of conversion function, and gives the possibility to define the activation energy against conversion degree as well. 
Application of abovementioned models allowed defining of thermodynamic parameters of thermal decomposition of hydrogel PMVE-MA with PPG graphically at different heating rates and conversion levels (Fig. 2, table 1, $a$ and $b$ ). Significant dependence of change of activation energy on transformation level should be mentioned (Fig. 2, a). This fact indicates that decomposition process of hydrogel PMVE-MA with PPG happens according to more than one process. In this case it is necessary to apply another kinetic method of research, more developed in the attempt to define and separate these processes, still unknown as Figure 2, $b$.
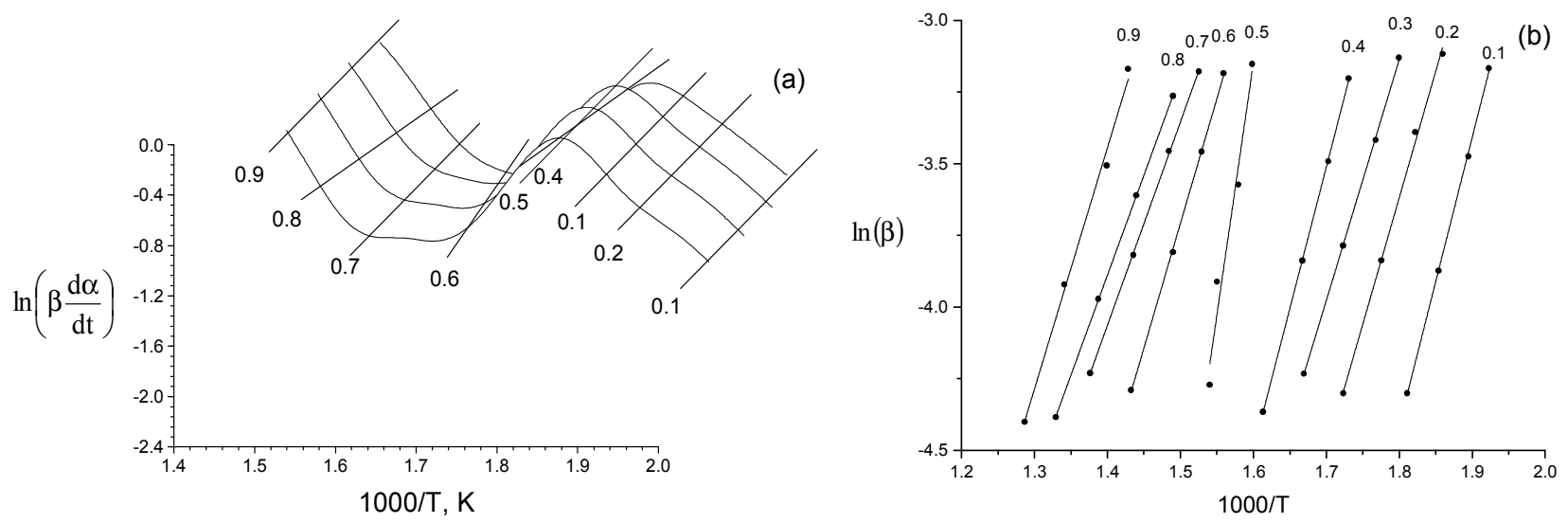

Figure 2. Graphic results of analysis, defined by methods of Friedman (a), Ozawa-Flynn-Wall (b) for hydrogel PMVE-MA with PPG

Attained values of dependence of activation energy on conversion level corresponds the second decomposition process and are shown in Table 1.

Table 1

Thermodynamic parameters of thermal decomposition of PMVE-MA with PPG, calculated with methods of Friedman (FR) and Ozawa-Flynn-Wall (OFW)

a) in nitrogen atmosphere

\begin{tabular}{|c|c|c|c|c|c|c|c|c|}
\hline \multirow{2}{*}{$\alpha$} & \multicolumn{3}{|c|}{ Friedman method } & \multicolumn{5}{c|}{ Ozawa-Flynn-Wall method } \\
\cline { 2 - 10 } & $E_{a}, \mathrm{~kJ} / \mathrm{mol}$ & $\delta_{(E)}$ & $\ln A \times 10^{3}, \mathrm{~min}^{-1}$ & $r$ & $E_{a}, \mathrm{~kJ} / \mathrm{mol}$ & $\delta_{(E)}$ & $\ln A \times 10^{3}, \mathrm{~min}^{-1}$ & $r$ \\
\hline 0.1 & 60.70 & 0.02 & 13.06 & 0.99 & 66.20 & 0.02 & 13.15 & 0.99 \\
\hline 0.2 & 60.45 & 0.01 & 11.61 & 0.96 & 66.95 & 0.12 & 12.20 & 0.96 \\
\hline 0.3 & 70.05 & 0.02 & 8.87 & 0.98 & 77.05 & 0.02 & 8.16 & 0.98 \\
\hline 0.4 & 79.21 & 0.14 & 9.59 & 0.97 & 76.20 & 0.18 & 6.88 & 0.97 \\
\hline 0.5 & 68.53 & 0.02 & 7.08 & 0.99 & 64.05 & 0.12 & 8.37 & 0.99 \\
\hline 0.6 & 81.15 & 0.11 & 4.71 & 0.98 & 99.15 & 0.01 & 5.00 & 0.98 \\
\hline 0.7 & 76.35 & 0.05 & 3.70 & 0.99 & 84.35 & 0.02 & 3.99 & 0.99 \\
\hline 0.8 & 87.95 & 0.12 & 2.65 & 0.98 & 87.95 & 0.11 & 2.94 & 0.98 \\
\hline 0.9 & 93.55 & 0.05 & 1.64 & 0.99 & 93.55 & 0.10 & 1.21 & 0.99 \\
\hline
\end{tabular}

b) in air atmosphere

\begin{tabular}{|c|c|c|c|c|c|c|c|c|}
\hline \multirow{2}{*}{$\alpha$} & \multicolumn{4}{|c|}{ Friedman method } & \multicolumn{4}{c|}{ Ozawa-Flynn-Wall method } \\
\cline { 2 - 10 } & $E_{a}, \mathrm{~kJ} / \mathrm{mol}$ & $\delta_{(E)}$ & $\ln A \times 10^{3}, \mathrm{~min}^{-1}$ & $r$ & $E_{a}, \mathrm{~kJ} / \mathrm{mol}$ & $\delta_{(E)}$ & $\ln A \times 10^{3}, \mathrm{~min}^{-1}$ & $r$ \\
\hline 0.1 & 66.32 & 0.02 & 14.66 & 0.99 & 61.32 & 0.02 & 15.71 & 0.99 \\
\hline 0.2 & 72.27 & 0.16 & 13.11 & 0.96 & 72.27 & 0.12 & 12.29 & 0.96 \\
\hline 0.3 & 77.12 & 0.02 & 11.27 & 0.98 & 77.12 & 0.02 & 10.17 & 0.98 \\
\hline 0.4 & 72.77 & 0.17 & 8.99 & 0.97 & 72.77 & 0.18 & 9.12 & 0.97 \\
\hline 0.5 & 78.87 & 0.02 & 9.48 & 0.99 & 78.87 & 0.12 & 6.10 & 0.99 \\
\hline 0.6 & 77.77 & 0.90 & 6.11 & 0.98 & 79.77 & 0.01 & 7.09 & 0.98 \\
\hline 0.7 & 89.97 & 0.02 & 5.10 & 0.99 & 89.97 & 0.02 & 2.11 & 0.99 \\
\hline 0.8 & 97.77 & 0.10 & 2.05 & 0.98 & 97.77 & 0.11 & 4.23 & 0.98 \\
\hline 0.9 & 106.52 & 0.02 & 1.00 & 0.99 & 106.52 & 0.10 & 2.41 & 0.99 \\
\hline
\end{tabular}


Use of definite value, defined for activation energy in estimation of thermal stability is risky. Even if standard deviation of values $\delta_{(\mathrm{E})}$ increases $10 \%$ of average value for each composition, it would be logic to avoid the comparison of quantitative values applying modeless values only.

\section{Processing of TG data applying modified NPK method}

Non-parametric kinetics method (NPK) [6-8] of Serra, Nomen and Sempere is based upon the suggestion that reaction velocity may be expresses as multiplication of two independent functions, $g(\alpha)$ and $f(T)$. Reaction model $g(\alpha)$ considers the dependence of conversion degree, and $f(T)$ considers the temperature dependence. Reaction velocity $\beta d \alpha / d T$ is measured by several experiments at different heating rates, $\beta$, was interpolated as the surface in $3 \mathrm{D}(\beta d \alpha / d T, \alpha, T)$. This surface is organized as matrix $i \times j$ where the lines correspond to different conversion degrees, from $\alpha_{1}$ to $\alpha_{i}$ and columns correspond to different temperatures from $T_{1}$ to $T_{j}$. Elements $i, j$ of matrix $A$, after $A_{i, j}=g\left(\alpha_{i}\right) f\left(T_{j}\right)$. Functions $g(\alpha)$ and $f(T)$ may be sampled and expressed as vector columns, $u_{0}$ and $v_{0}$, respectively, where elements and sampled values of function $g(\alpha)$ and $f(T)$.

$$
\begin{aligned}
u_{0} & =\left\{g\left(\alpha_{1}\right) g\left(\alpha_{2}\right) \ldots g\left(\alpha_{i}\right)\right\} ; \\
v_{0} & =\left\{f\left(T_{1}\right) f\left(T_{2}\right) \ldots f\left(T_{j}\right)\right\} .
\end{aligned}
$$

Reaction speed may be expressed in the form of matrix as follows:

$$
A=u_{0} \cdot v_{0}^{T} .
$$

NPK method applied the algorithm of single value decomposition (SVD) for decomposition of matrix $A$ into two vectors $u_{0}$ and $v_{0}$. These vectors may be further analyzed by check of attained graphs of velocity dependence on $\alpha$ (to define the kinetic model) and velocity dependence on temperature (to define Arrhenius parameters). Vector $u_{0}$ is defined by first column of matrix $U$ and $v_{0}$ from the first column of matrix $V$, where:

$$
A=U(\text { diag. } s) V^{T}
$$

and $s$ is the vector of singular value.

Under values $\alpha, \beta d \alpha / d T$ and $T$ taken from data attained by TG, DTG methods, reaction velocity surface was attained in coordinate space $(\alpha, T$ and $\beta(d \alpha / d T))$ (Fig. 3).

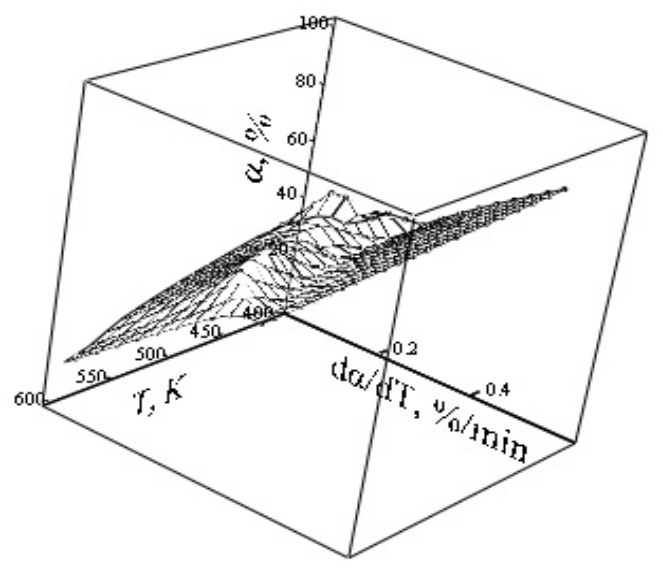

Figure 3. Surface of hydrogel PMVE-MA with PPG in coordinate space:

dependence of reaction velocity $(d \alpha / d T)$ on temperature $(T)$ and conversion degree $(\alpha)$

After application of algorithm of single value decomposition (SVD), matrix $A$ is a vector $s$ with two significant values. In this case matrix $A$ is a sum total of the following:

$$
A=A_{1}+A_{2}=u_{1} \cdot v_{1}^{T}+u_{2} \cdot v_{2}^{T} \text {. }
$$

This means that there are two elementary processes in decomposition level, and discrimination between them is possible by values of explained variance) $\lambda_{1}$ and $\lambda_{2}\left(\lambda_{1}+\lambda_{2} \approx 100 \%\right)$.

Vectors $u_{1}$ and $u_{2}$ were checked against the equation of Šestak-Berggren [9] (Fig. 4)

$$
\mathrm{g}(\alpha)=\alpha^{m}(1-\alpha)^{n}[-\ln (1-\alpha)]^{p}
$$


and vectors $v_{1}$ and $v_{2}$, against the equation of Arrhenius, respectively (Fig. 5). Results of kinetic analysis are shown in Table 2.
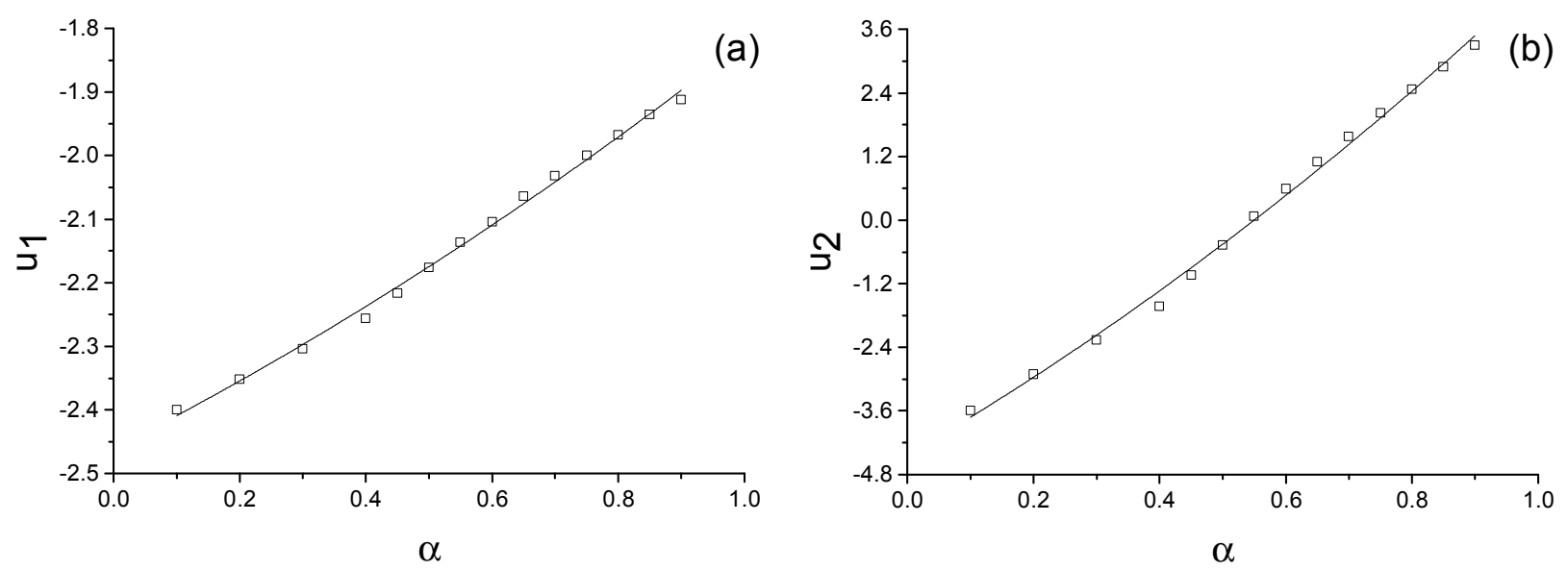

$a$ - main process; $b$ - secondary process

Figure 4. Simulated and determined values of the normalized vectors $u$ for sample PMVE-MA with PPG
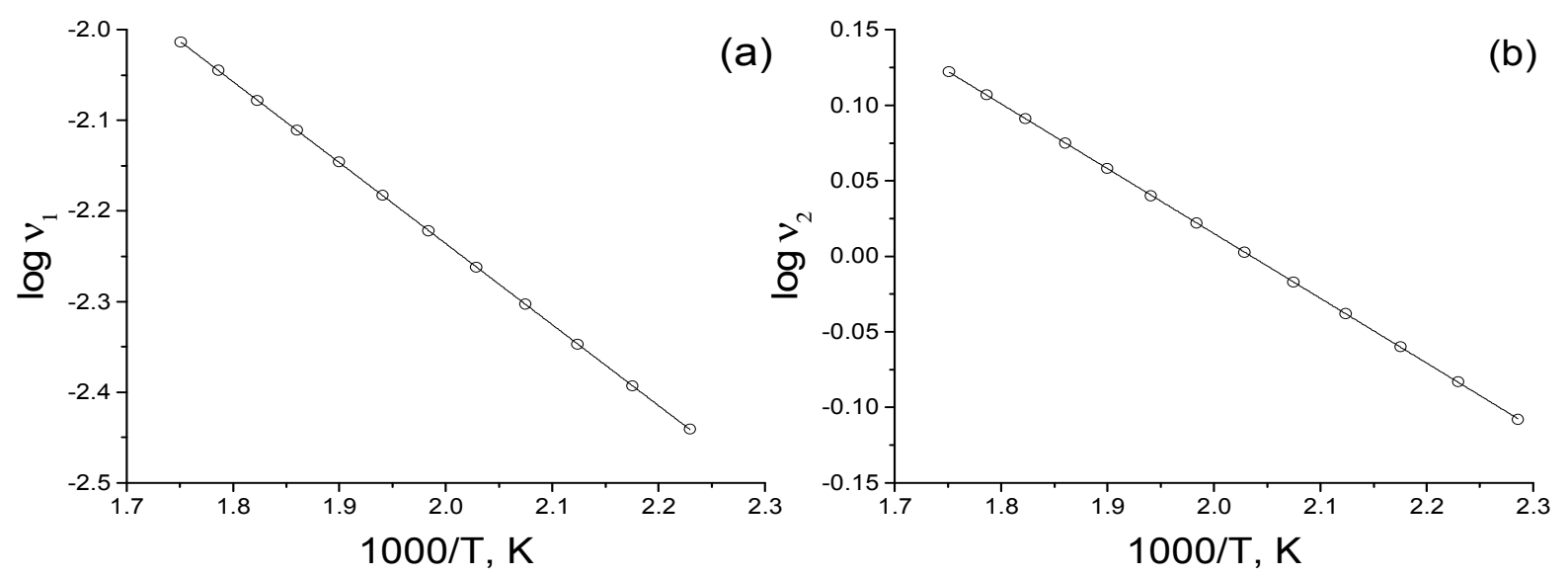

$a$ - main process; $b$ - secondary process

Figure 5. Linearized Arrhenius equation (ln $v$ vs. 1000/T)

Table 2

Kinetic parameters of thermal decomposition of hydrogel PMVE-MA with PPG calculated by method of non-parametric kinetics (NPK)

\begin{tabular}{|c|c|c|c|c|c|c|c|c|}
\hline \multicolumn{2}{|c|}{ Sample } & $\lambda, \%$ & $E_{a}, \mathrm{~kJ} / \mathrm{mol}$ & $A, \mathrm{~s}^{-1}$ & $n$ & $m$ & $\begin{array}{c}\text { Šestak-Berggren } \\
g(\alpha)=\alpha^{m}(1-\alpha)^{n}\end{array}$ & $\begin{array}{c}\sum \lambda \cdot E_{a}, \\
\mathrm{~kJ} / \mathrm{mol}\end{array}$ \\
\hline \multirow{6}{*}{$\begin{array}{l}\text { PMVE-MA } \\
\text { with PPG }\end{array}$} & & & & in a nit & en at & sph & & \\
\hline & 1 & 57.8 & 59.56 & $0.06 \times 10^{5}$ & $4 / 5$ & $1 / 3$ & $(1-\alpha)^{4 / 5} \cdot \alpha^{1 / 3}$ & \multirow{2}{*}{99.47} \\
\hline & 2 & 42.2 & 92.23 & $6.42 \times 10^{5}$ & - & 2 & $\alpha^{2}$ & \\
\hline & \multicolumn{8}{|c|}{ in air } \\
\hline & 1 & 62.1 & 60.38 & $0.12 \times 10^{5}$ & $4 / 5$ & $1 / 3$ & $(1-\alpha)^{4 / 5} \cdot \alpha^{1 / 3}$ & \multirow{2}{*}{115.15} \\
\hline & 2 & 37.9 & 108.07 & $4.41 \times 10^{5}$ & - & 2 & $\alpha^{2}$ & \\
\hline
\end{tabular}


Values of explained variance make clear that sample, decomposed by us, is met in separate processes $\left(\lambda_{2} \approx 50 \%\right)$ and this is related to the lower level of thermal stability (minimum value of activation energy). In comparison with II stage, it represents the significant process of thermal decomposition.

Overrun of this process to TG curve is definitely caused by kinetic influence (of value $E_{a}$ ). Parameter $n=4 / 5$ (eq. (6) and table 2) denotes the decomposition of condensed phase, weight loss $\approx 75 \%$ on TG curve. These data correspond to the decomposition after melting of combinations. Values, $m=1 / 3$ may be conditioned by diffusion influence on kinetic law.

\title{
Conclusions
}

Thus, to calculate the kinetic parameters of thermal destruction of PMVE-MA with PPG isoconversion models of Friedman, Ozawa-Flynn-Wall may be applied, which proved themselves at thermal analysis of non-organic compositions. Value of kinetic model parameters calculated applying these models, are true enough. However, to our opinion, the most appropriate model is the non-parametric kinetics method, as the advantage of this method of analysis is in the fact that calculation result does not depend on type of kinetic equation $g(\alpha)$.

\section{References}

1 Hemminger, W., \& Höhne, G. (1984). Calorimetry. Fundamentals and Practice. Basel: Verlag Chemia GmbH.

2 Opfermann, J. (2000). Kinetic analysis using multivariate nonlinear regression. Journal of Thermal Analysis and Calorimetry, 60, 2, 641-658.

3 Friedman, H.L. (1964). Kinetics of thermal degradation of char-forming plastics from thermogravimetry. Application to a phenolic plastic. Journal of Polymer Science Part C: Polymer Symposia, 6, 1, 183-195.

4 Flynn, J.H., \& Wall, L.A. (1966). A quick, direct method for the determination of activation energy from thermogravimetric data. Journal of Polymer Science Part B: Polymer Letters, 4, 5, 323-328.

5 Wall, M.E., Rechtsteiner, A., \& Rocha, L.M. (2003). Singular Value Decomposition and Principal Component Analysis. A Practical Approach to Microarray Data Analysis, 91-109.

6 Serra, R., Nomen, R., \& Sempere, J. (1998). The Non-Parametric Kinetics A New Method for the Kinetic Study of Thermoanalytical Data. Journal of Thermal Analysis and Calorimetry, 52, 3, 933-943.

7 Serra, R., Nomen, R., \& Sempere, J. (1998). A new method for the kinetic study of thermoanalytical data: The nonparametric kinetics method. Thermochimica Acta, 316, 1, 37-45.

8 Serra, R., Nomen, R., \& Sempere, J. (1999). Progress in Non-parametric Kinetics. Journal of Thermal Analysis and Calorimetry, 56, 2, 843-849.

9 Albu, P., Bolcu, C., Vlase, G., Doca, N., \& Vlase, T. (2011). Kinetics of degradation under non-isothermal conditions of a thermooxidative stabilized polyurethane. Journal of Thermal Analysis and Calorimetry, 105, 2, 685-689.

\author{
А.Ж. Сарсенбекова, А.И. Халитова, А.А. Шахабаева
}

\section{Термогравиметрия нәтижелері бойынша полипропиленгликольмен тігілген полиметилвенилэфирмалеин қышқылы негізіндегі гидрогельдің изотермиялық көрсеткіштерін өңдеу}

\author{
ПЕК әдісі бойынша салыстырмалы кинетикалық талдау
}

\begin{abstract}
Динамикалық термогравиметрия нәтижелері бойынша полипропиленгликольмен тігілген полиметилвинил эфир малеин қышқылы негізіндегі гидрогельдің термодеструкциясының кинетикалық көрсеткіштерін есептеудің әртүрлі әдістері келтірілген. Зерттеу азот пен ауа атмосферасында қызу жылдамдығы әртүрлі жағдайда жүргізілді: 6, 10, 12 және 16 K/мин. Берілген сополимер үшін изоконверсионды әдіс тобына жататын Фридман, Флинн-Озав-Уолл әдістерін қолдану анағұрлым мақсатты әрекет етеді. Көрінген нәтижелер әртүрлі әдіспен алынған белсенді энергия көрсеткіштерінің сәйкес келуін анық көрсетеді. Толық кинетикалық талдау үшін параметрлік емес (ПЕК), кинетикалық әдісті қолдана отырып зерттеу нәтижелерін өңдеу керек. ПЕК кинетикалық деректерді ерекше өңдеу тәсілін көрсетеді. Бұл әдіс кинетикалық талдауды басқа жағынан сипаттайды, яғни ол бір стадиялық үдерістің нәтижелерін дөңгелектеуіне негізделген. Реакция жылдамдығының эксперименталды мағынасы матрицада орналасқан, ол $f(T)$ және $g(\alpha)$ туралы ақпараттан тұратын екі вектордың туындысымен сипатталды.
\end{abstract}

Кілт сөздер: динамикалық термогравиметрия, термиялық талдау, термодеструкция, гидрогель. 
А.Ж. Сарсенбекова, А.И. Халитова, А.А. Шахабаева

\section{Обработка изотермических данных гидрогеля на основе полиметилвинилового эфира малеиновой кислоты, сшитого полипропиленгликолем по данным термогравиметрии}

\section{Сравнительный кинетический анализ методом НПК}

В статье представлен анализ различных методов расчета кинетических параметров термодеструкции гидрогеля на основе полиметилвинилового эфира малеиновой кислоты, сшитого полипропиленгликолем по данным динамической термогравиметрии. Исследования были произведены в атмосфере азота и воздуха при различных скоростях нагрева: $6,10,12$ и $16 \mathrm{~K} /$ мин. Показано, что для данного сополимера наиболее целесообразно использовать методы Фридмана, Флинн-Озава-Уолла, относящиеся к группе изоконверсионных методов. Результаты указывают на достаточно хорошее совпадение между значениями энергии активации, полученных разными методами. Для получения полного кинетического анализа необходима обработка данных с использованием метода непараметрической кинетики (НПК). Метод НПК представляет собой особый подход для обработки кинетических данных, а также новую точку зрения на кинетический анализ, который основан на округлении результатов кинетики одностадийного процесса. Экспериментальные значения скорости реакций расположены в матрице, которая выражается как произведение двух векторов, содержащих информацию по $f(T)$ и $g(\alpha)$.

Ключевые слова: динамическая термогравиметрия, термический анализ, термодеструкция, гидрогель. 